\title{
The impact of aspirin, statins and ACE-inhibitors on the presentation of colorectal neoplasia in a colorectal cancer screening programme
}

\author{
D Mansouri ${ }^{\star}, 1$, D C McMillan ${ }^{1}$, C S D Roxburgh ${ }^{1}$, E M Crighton ${ }^{2}$ and P G Horgan ${ }^{1}$ \\ ${ }^{1}$ Academic Department of Surgery, School of Medicine-University of Glasgow, Glasgow Royal Infirmary, Glasgow G4 0SF, UK \\ and ${ }^{2}$ Department of Public Health Screening Unit, NHS Greater Glasgow and Clyde, West House, Gartnavel Royal Hospital, \\ Glasgow G12 OXH, UK
}

Background: There is increasing evidence that aspirin, statins and ACE-inhibitors can reduce the incidence of colorectal cancer. The aim of the present study was to assess the impact of these medications on an individual's risk of advanced neoplasia in a colorectal cancer screening programme.

Methods: A prospectively maintained database of the first round of screening in our geographical area was analysed. The outcome measure was advanced neoplasia (cancer or intermediate or high risk adenomata).

Results: Of the 4188 individuals who underwent colonoscopy following a positive occult blood stool test, colorectal pathology was present in 3043(73\%). Of the 3043 patients with colorectal pathology, 1704(56\%) had advanced neoplasia. Patients with advanced neoplasia were more likely to be older (OR 1.38; 95\% Cl 1.19-1.59) and male (OR 1.66; 95\% Cl 1.43-1.94) (both P<0.001). In contrast, those on aspirin (OR 0.68; 95\% Cl 0.56-0.83), statins (OR 0.65; 95\% Cl 0.55-0.78) or ACE inhibitors (OR 0.71; 95\% Cl $0.57-0.89$ ) were less likely to have advanced neoplasia at colonoscopy (all $P<0.05$ ).

Conclusion: In patients undergoing colonoscopy following a positive occult blood stool test with documented evidence of aspirin, statin or ACE-inhibitor usage, advanced neoplasia is less likely, suggesting that the usage of these medications may have a chemopreventative effect.

Colorectal cancer is the third most common cancer in the Western world and is second only to lung cancer as a cause of cancer death in the combined male and female populations in the United Kingdom. Around 40000 people are diagnosed with bowel cancer each year in the United Kingdom alone and around 16000 deaths occur annually from the disease. Incidence increases with age, with over $80 \%$ of cases occurring in patients over the age of 60 years (Cancer Research UK).

There is good evidence that screening for colorectal cancer using the guaiac-based faecal occult blood test (gFOBt) increases the number of early-stage cancers diagnosed (Dukes A and B) and consequently reduces cancer-specific mortality (Mandel et al, 1993; Hardcastle et al, 1996; Kronborg et al, 1996). In addition, there is increasing evidence that screening using the faecal immunochemical test (FIT), where the level of blood in the stool can be quantified, may have improved sensitivity over gFOBt, albeit with higher positivity rates and slight reductions in specificity (Guittet et al, 2007; Hol et al, 2009; Parra-Blanco et al, 2010). This has lead to the development of a gFOBt/FIT population-based screening programme in Scotland, where individuals with a weakly positive result on initial gFOBt testing are sent a confirmatory FIT (Fraser et al, 2012). Despite this, interval cancers do develop (Steele et al, 2009). 
This number appears to increase with successive screening rounds, suggesting that while screening is good at targeting so called screen-detected cancers, a proportion of tumours are resistant to the screening process in its current form (Steele et al, 2009, 2012).

Therefore, there is substantial ongoing interest in the field of chemoprevention, with the use of certain drugs to reduce an individual's risk of cancer. For example, there is considerable evidence that aspirin may reduce an individual's likelihood of developing both pre-cancerous adenomata (Baron et al, 2003; Benamouzig et al, 2003; Sandler et al, 2003; Cole et al, 2009) and colorectal cancer (Thun et al, 1991; Flossmann and Rothwell, 2007). Moreover, it may have an impact on reducing cancer deaths in those with colorectal tumours (Rothwell et al, 2010, 2011). The precise mechanism for aspirin's effect is not entirely clear but appears to be due to both its role in modulating the inflammatory response and also through more complex direct effects on tumour cells themselves (Chan et al, 2012).

In addition, statins have also been suggested to reduce an individual's risk of developing both colorectal cancer and advanced adenomas. The evidence for this has been variable in individual trials (Poynter et al, 2005; Jacobs et al, 2011; Simon et al, 2012); however, a recent meta-analysis involving 11 randomised control trials, 13 case-control studies and 8 cohort studies concluded that chronic statin usage did indeed have a small protective impact on colorectal cancer occurrence (Bardou et al, 2010). The mechanism for its effect is thought to arise through a combination of increased induction of tumour cell apoptosis, inhibition of cell growth or angiogenesis, or through enhancement of the immune response (Gauthaman et al, 2009).

Furthermore, some evidence has emerged that angiotensinconverting enzyme inhibitors (ACE-i) may also have a chemopreventative effect (Lever et al, 1998), and in particular for colonic cancer their use may reduce the development of pre-cancerous adenomata (Kedika et al, 2011). This may be owing to a role of angiotensin-converting enzyme in influencing local tumour growth and neoangiogenesis (Rocken et al, 2007).

However, each of these drugs each has their own side-effect profile. This may be magnified when used in high doses, and so far no single agent has been recommended for chemopreventive use in the general population. Use of these drugs for chemoprevention in combination has previously been suggested (Zhou et al, 2012) but not studied in a population setting; however, the concept of a 'polypill' to reduce cardiovascular risk has previously been proposed (Wald and Law, 2003; Rodgers et al, 2011).

The aim of the present study was to assess the affect of aspirin, statins and ACE-i both in isolation and in combination, on an individual's risk of neoplasia in patients who tested positive in a colorectal cancer screening programme and subsequently underwent colonoscopy.

\section{PATIENTS AND METHODS}

Beginning in April 2009, all males and females between the age of 50 and 74 and registered with a GP in NHS Greater Glasgow and Clyde (NHS GG\&C) were identified via their Community Health Index and invited to participate in the Scottish Bowel Screening Programme (SBoSP). Participants were sent a gFOBt kit and asked to provide two samples from three separate faecal specimens. In the case of weakly positive or spoiled kits, participants were sent a FIT kit. Analysis and processing of the gFOBt/FIT kits in the SBoSP has been described previously (Fraser et al, 2012). Following a positive result, patients were pre-assessed, either face-to-face or following telephone consultation, by a bowel screening endoscopy nurse and then referred on for colonoscopy if this was deemed suitable. Details on patient medications were automatically uploaded to the Bowel Screening IT system from the Scottish Care Information Gateway system, which provides an interface between primary and secondary care records. This allows for details of patients regular medication, as held by their General Practitioner to be obtained. As part of the pre-assessment interview, patient medications were checked with this electronic record. A user of medication was defined as an individual who had either aspirin, statin or ACE-i usage at time of pre-assessment documented as per this method. Patient details were obtained from the prospectively maintained Bowel Screening IT system managed by the Public Health Screening Unit at NHS GG\&C.

Data on endoscopic findings and pathological diagnosis were obtained retrospectively from clinical information systems. The presence of any colorectal pathology that could account for a positive stool test was noted. This included, but was not limited to, colorectal cancer, dysplastic polyps and non-neoplastic colorectal pathology such as colitis or haemorrhoids. The presence of uncomplicated diverticulosis and hyperplastic polyps were noted as normal findings.

In those patients in whom a pathological diagnosis of dysplastic polyps was reached, they were classified as being of a low risk, intermediate risk or high risk of subsequent development of colorectal cancer as per British Society of Gastroenterology (BSG) guidelines (Atkin and Saunders, 2002) (low risk: 1 to 2 polyps $<1 \mathrm{~cm}$; intermediate risk: $3-4$ polyps $<1 \mathrm{~cm}$ or $\geqslant 1$ polyp $\geqslant 1 \mathrm{~cm}$; high risk: $\geqslant 5$ polyps or $\geqslant 3$ polyps of which $\geqslant 1$ is $\geqslant 1 \mathrm{~cm}$ ). Advanced neoplasia was defined as patients with either colorectal cancer or dysplastic polyps classified as intermediate or high risk as per BSG guidelines.

Deprivation category was calculated using the Scottish Index of Multiple Deprivation (SIMD), which is an index of relative deprivation combining 38 indicators across 7 domains, namely, income, employment, health, education, skills and training, housing, geographic access and crime. The overall index is a weighted rank for each domain allowing postcodes to be ranked in order of deprivation across Scotland. Quintiles of deprivation were used to assign patients a relative deprivation category based on their postcode at the time of colonoscopy with the first quintile representing the most deprived and the fifth quintile the least deprived (http://www.scotland.gov.uk/Topics/Statistics/SIMD).

Permission for the study was granted by the Caldicott Guardian of the data, and data was stored and analysed in an anonymised manner.

Statistical analysis. Associations between categorical variables were examined using $\chi^{2}$ tests for linear trend unless otherwise specified. Both univariate and multivariate logistical regression was used to calculate odds ratios. A value of $P<0.05$ was considered statistically significant. Statistical analysis was performed using SPSS software (SPSS Inc., Chicago, IL, USA).

\section{RESULTS}

From April 2009 to March 2011 representing the first complete round of screening in NHS GG\&C, 395096 individuals were invited to participate, 204461 (52\%) responded and 6085 (3\%) tested positive. Of those who tested positive, 4631 (76\%) patients proceeded to undergo colonoscopy. Complete results on both outcomes following colonoscopy and medications noted at preassessment were available for 4188 (90\%) patients, which formed the basis of our analysis (Figure 1). The majority of positive results were owing to a positive FIT (3449 (82\%) patients).

Presence of colorectal pathology. Of the 4188 patients in whom complete results were available, colorectal pathology was identified in $3043(73 \%)$ patients (Figure 2). Patients with colorectal 


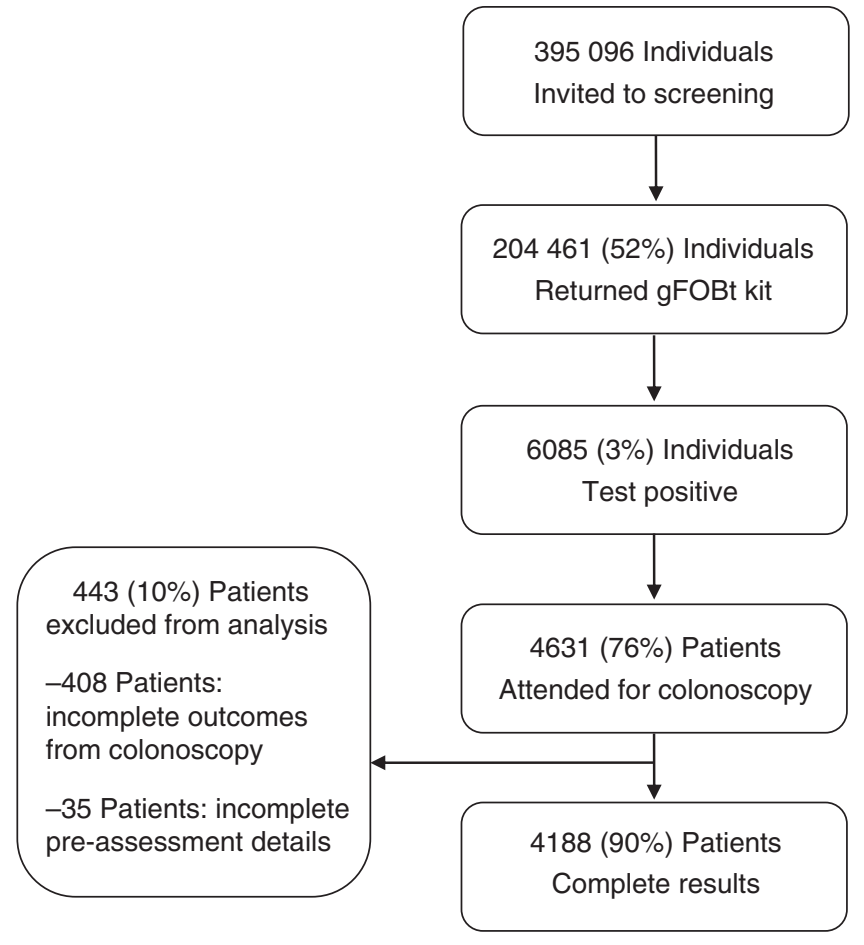

Figure 1. Flow diagram of cohort.

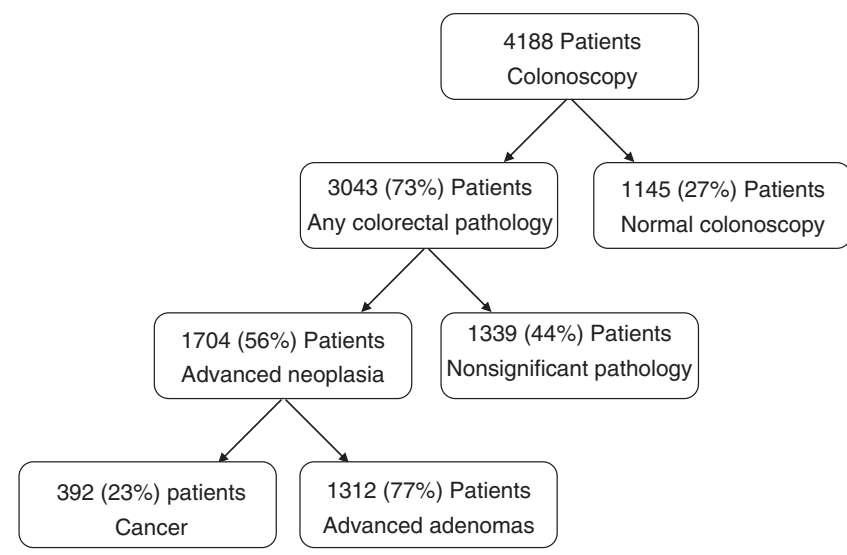

Figure 2. Outcome from colonoscopies. Any colorectal pathology is any colorectal pathology that could account for a positive stool test (cancer, dysplastic polyps and non-neoplastic colorectal pathology including, but not limited to, colitis and haemorrhoids). Advanced neoplasia $=$ colorectal cancer, $>3$ dysplastic polyps $<1 \mathrm{~cm}$ or $>1$ dysplastic polyp $\geqslant 1 \mathrm{~cm}$. Advanced adenomas $=3$ dysplastic polyps $<1 \mathrm{~cm}$ or $>1$ dysplastic polyp $\geqslant 1 \mathrm{~cm}$.

pathology were more likely to be older $(P<0.001)$, male $(P<0.001)$, less deprived $(P<0.05)$ and have tested positive through gFOBt route $(P<0.05)$ than those without any (Table 1). In contrast, those that were on aspirin were less likely to have colorectal pathology identified at colonoscopy $(P<0.05)$. There were no associations between statin or ACE-i usage and the presence of colorectal pathology. On multivariate analysis, older age and male sex remained associated with increased risk of colorectal pathology (both $P<0.001$ ) and aspirin usage remained associated with a reduced risk of colorectal pathology $(P<0.001)$.

Presence of advanced neoplasia. Of the 3043 patients with colorectal pathology, advanced neoplasia was identified in 1704 (56\%) patients (Figure 2). Patients with advanced neoplasia were more likely to be older, male, less deprived and have tested positive through the gFOBt route (all $P<0.001$ ) than those without (Table 2). In contrast, those on aspirin $(P<0.001)$, statins $(P<0.001)$ or ACE-i $(P<0.05)$ were all less likely to have advanced neoplasia at colonoscopy. As the majority of patients on at least one of these medications were in fact on multiple medications for the purposes of multivariate analysis, the variable $\geqslant 1$ medication was entered into the model. The associations identified on univariate analysis persisted in the multivariate model. The risk of advanced neoplasia was also then examined in medication combinations (Table 3). Similar odds ratios were seen between combinations of these three medications (OR 0.64; $95 \%$ CI $0.50-0.83$ to $0.71 ; 95 \%$ CI $0.57-0.89$ ) where the risk of nonsignificant pathology was taken as the reference. Odds ratios for those on $\geqslant 1$ medication (OR $0.67 ; 95 \%$ CI $0.56-0.78$ ) or $\geqslant 2$ medications (OR 0.67; 95\% CI 0.55-0.81) were also similar.

Presence of cancer. Of the 1704 patients with advanced neoplasia, colorectal cancer was identified in 392 (23\%) patients (Figure 2). Patients with cancer were more likely to be older $(P=0.001)$, female $(P<0.05)$ and have tested positive through the gFOBt route $(P<0.001)$ than those with advanced adenomas only (Table 4$)$. These associations remained significant on multivariate analysis. There was a nonsignificant trend to those with cancer identified being less likely to be on a statin $(14 \%$ vs $18 \%, P=0.071)$.

DISCUSSION

The results of the present study report, for the first time, a reduced incidence of advanced neoplasia in patients who are on a statin or an ACE-i that undergo colonoscopy following a positive stool test within a population-based colorectal cancer screening programme. In addition, it confirms previous work that has shown a reduced incidence of advanced neoplasia in those on aspirin. Overall, the results suggest that there may be role for population-based usage of these medications in reducing the incidence of colorectal neoplasia.

The reduction in the incidence of advanced neoplasia of 33\% in those on at least one medication is similar to the $28 \%$ reduction seen in a recent meta-analysis of the effect of aspirin in preventing advanced lesions in a non-screened population (Cole et al, 2009). Studies have also previously shown a lower yield of neoplasia in those on aspirin who undergo a colonoscopy following a positive gFOBt (Clarke et al, 2006; Sawhney et al, 2010; Lee et al, 2012). However, previous work has been unable to adjust for the falsepositive effect of aspirin that can occur with gFOBt tests, and therefore were unable to definitively attribute this to a chemopreventative effect. For example, there is evidence that aspirin can increase gFOBt false positives due to its antiplatelet activity causing occult bleeding in an otherwise normal gastrointestinal tract. In the present study, by removing all those in whom no cause for the positive stool test was found, the impact of this confounding factor was minimised. Furthermore, the majority of our patients tested weakly positive on gFOBt and actually proceeded to colonoscopy only following a confirmatory positive FIT. Indeed, previous authors have reported a limited effect of aspirin usage on FIT specificity (Levi et al, 2009; Brenner et al, 2010).

In addition, the reduced incidence of advanced neoplasia that was seen in the present study was seen not only in aspirin but in statins and ACE-i that have not previously been reported to cause false-positive stool tests. The present study supports this assumption as aspirin but neither statins nor ACE-i usage was associated with a higher likelihood of having a normal colonoscopy.

The stage at which these medications might impact on the adenoma-carcinoma sequence has been previously speculated (Rocken et al, 2007; Gauthaman et al, 2009; Chan et al, 2012). Of interest, in the present study there was no significant impact of medications on the presence of cancer within those with advanced 
Table 1. Study population and risk of detecting any colorectal pathology at colonoscopy following a positive stool test

\begin{tabular}{|c|c|c|c|c|c|c|c|c|c|c|}
\hline & \multicolumn{2}{|c|}{$\begin{array}{c}\text { All } \\
\text { patients }\end{array}$} & \multicolumn{2}{|c|}{$\begin{array}{l}\text { Colorectal } \\
\text { pathology }\end{array}$} & \multicolumn{2}{|c|}{$\begin{array}{c}\text { Normal } \\
\text { colonoscopy }\end{array}$} & \multirow[b]{2}{*}{$\boldsymbol{P}$-value } & \multirow{2}{*}{$\begin{array}{c}\text { Risk of colorectal } \\
\text { pathology } \\
\text { (multivariate } \\
\text { analysis) }\end{array}$} & \multirow[b]{2}{*}{$95 \% \mathrm{Cl}$} & \multirow[b]{2}{*}{$P$-value } \\
\hline & $\mathbf{n}$ & $\%$ & $n$ & $\%$ & $n$ & $\%$ & & & & \\
\hline & 4188 & & 3043 & & 1145 & & & & & \\
\hline \multicolumn{11}{|l|}{ Age } \\
\hline $\begin{array}{l}\leqslant 55 \\
56-64 \\
\geqslant 65\end{array}$ & $\begin{array}{c}877 \\
1280 \\
2031\end{array}$ & \begin{tabular}{|l|}
21 \\
31 \\
49
\end{tabular} & $\begin{array}{c}565 \\
925 \\
1553\end{array}$ & $\begin{array}{l}19 \\
30 \\
51\end{array}$ & $\begin{array}{l}312 \\
355 \\
478\end{array}$ & $\begin{array}{l}27 \\
31 \\
42\end{array}$ & $<0.001$ & $\begin{array}{c}1 \\
1.41 \\
1.89 \\
\end{array}$ & $\begin{array}{l}1.17-1.71 \\
1.58-2.27\end{array}$ & $\begin{array}{l}<0.001 \\
<0.001\end{array}$ \\
\hline \multicolumn{11}{|l|}{ Sex } \\
\hline $\begin{array}{l}\text { Male } \\
\text { Female }\end{array}$ & $\begin{array}{l}2489 \\
1699\end{array}$ & \begin{tabular}{|l|}
59 \\
41
\end{tabular} & $\begin{array}{l}1990 \\
1053\end{array}$ & $\begin{array}{l}65 \\
35\end{array}$ & $\begin{array}{l}499 \\
646\end{array}$ & $\begin{array}{l}44 \\
56\end{array}$ & $<0.001$ & $\begin{array}{c}1 \\
2.49\end{array}$ & $2.16-2.86$ & $<0.001$ \\
\hline \multicolumn{11}{|c|}{ Deprivation category } \\
\hline $\begin{array}{l}1 \text { (most deprived) } \\
2 \\
3 \\
4 \\
5 \text { (least deprived) }\end{array}$ & $\begin{array}{l}1506 \\
785 \\
666 \\
527 \\
699\end{array}$ & \begin{tabular}{|l|}
36 \\
19 \\
16 \\
13 \\
17
\end{tabular} & $\begin{array}{c}1060 \\
568 \\
507 \\
380 \\
525\end{array}$ & $\begin{array}{l}35 \\
19 \\
17 \\
13 \\
17\end{array}$ & $\begin{array}{l}446 \\
217 \\
159 \\
147 \\
174\end{array}$ & $\begin{array}{l}39 \\
19 \\
14 \\
13 \\
15\end{array}$ & 0.017 & $\begin{array}{c}1 \\
1.08 \\
1.30 \\
1.02 \\
1.21\end{array}$ & $\begin{array}{l}0.88-1.31 \\
1.05-1.61 \\
0.81-1.28 \\
0.98-1.49\end{array}$ & $\begin{array}{l}0.461 \\
0.017 \\
0.879 \\
0.080\end{array}$ \\
\hline \multicolumn{11}{|c|}{ Type of positive stool test } \\
\hline $\begin{array}{l}\text { gFOBt } \\
\text { FIT }\end{array}$ & $\begin{array}{c}739 \\
3449\end{array}$ & \begin{tabular}{|l|}
18 \\
82
\end{tabular} & $\begin{array}{c}561 \\
2482\end{array}$ & $\begin{array}{l}18 \\
82\end{array}$ & $\begin{array}{l}178 \\
967\end{array}$ & $\begin{array}{l}16 \\
84\end{array}$ & 0.029 & $\begin{array}{c}1 \\
1.20\end{array}$ & $0.99-1.45$ & 0.062 \\
\hline \multicolumn{11}{|l|}{ Aspirin } \\
\hline $\begin{array}{l}\text { No } \\
\text { Yes }\end{array}$ & $\begin{array}{c}3531 \\
657\end{array}$ & \begin{tabular}{|l|}
84 \\
16 \\
\end{tabular} & $\begin{array}{c}2592 \\
451\end{array}$ & $\begin{array}{l}85 \\
15\end{array}$ & $\begin{array}{l}939 \\
206\end{array}$ & $\begin{array}{l}82 \\
18\end{array}$ & 0.012 & $\begin{array}{c}1 \\
0.67\end{array}$ & $0.55-0.81$ & $<0.001$ \\
\hline \multicolumn{11}{|l|}{ Statin } \\
\hline $\begin{array}{l}\text { No } \\
\text { Yes }\end{array}$ & $\begin{array}{c}3308 \\
880\end{array}$ & \begin{tabular}{|l|}
79 \\
21
\end{tabular} & $\begin{array}{c}2422 \\
621\end{array}$ & $\begin{array}{l}80 \\
20\end{array}$ & $\begin{array}{l}886 \\
259\end{array}$ & $\begin{array}{l}77 \\
23\end{array}$ & 0.117 & & & \\
\hline \multicolumn{11}{|l|}{ ACE inhibitor } \\
\hline $\begin{array}{l}\text { No } \\
\text { Yes }\end{array}$ & $\begin{array}{c}3682 \\
506\end{array}$ & \begin{tabular}{|l|}
88 \\
12
\end{tabular} & $\begin{array}{c}2672 \\
371\end{array}$ & $\begin{array}{l}88 \\
12\end{array}$ & $\begin{array}{c}1010 \\
165\end{array}$ & $\begin{array}{l}88 \\
12\end{array}$ & 0.722 & & & \\
\hline \multicolumn{11}{|l|}{$\geqslant 1$ Medications } \\
\hline $\begin{array}{l}\text { No } \\
\text { Yes }\end{array}$ & $\begin{array}{l}3088 \\
1100\end{array}$ & \begin{tabular}{|l|}
74 \\
26 \\
\end{tabular} & $\begin{array}{c}2271 \\
772\end{array}$ & $\begin{array}{l}75 \\
25 \\
\end{array}$ & $\begin{array}{l}817 \\
328\end{array}$ & $\begin{array}{l}71 \\
29\end{array}$ & 0.032 & & & \\
\hline
\end{tabular}

neoplasia. Therefore, it may indicate that rather than affecting cancer progression and growth, these medications exert their influence earlier in the adenoma-carcinoma pathway by preventing adenoma development.

From previous in vivo and in vitro studies, there is not only debate as to which stage of the adenoma-carcinoma sequence is affected by both aspirin, statins and ACE-i but also the precise mechanism of action. For example, with aspirin, there is evidence for both a direct local effect on tumour cells and the tumour microenvironment, and a systemic effect of the drug on circulating inflammatory cytokines (Chan et al, 2012). The clinical limitations with many in-vitro studies are that large concentrations of aspirin are required to create a local effect. While not specifically noted, it is likely that the vast majority of patients in the present study were taking low doses designed for cardiac prevention and therefore the local effects on colonic mucosa were likely to be limited. This favours the premise that the reduction in neoplasia seen in the present study is mediated through a systemic effect. If this was proven to be the case, then the reduction in neoplasia risk detected by the present study is likely to be an underestimation owing to the non-discriminatory use of these medications. There is evidence that an elevated host systemic inflammatory response is associated with the presence of cancer (Proctor et al, 2010) and hence it may be that more targeted therapy to those at risk of neoplasia, for example, with an elevated systemic inflammatory response, may yield a greater benefit. It would be of interest to examine medication usage, neoplasia risk and markers of the systemic inflammatory response within population studies and further work is warranted.

It is important to note that conclusions drawn from the present study may not necessarily be representative of the population as a whole who were invited to screening. Only 52\% of patients responded to the screening invite and just over three quarters of those who tested positive actually underwent colonoscopy. We have previously reported that those who fail to respond to screening are more likely to be male, younger and more socio- 
Table 2. Risk of advanced neoplasia in those with colorectal pathology at colonoscopy

\begin{tabular}{|c|c|c|c|c|c|c|c|c|c|c|}
\hline & \multicolumn{2}{|c|}{$\begin{array}{c}\text { All } \\
\text { patients }\end{array}$} & \multicolumn{2}{|c|}{$\begin{array}{l}\text { Advanced } \\
\text { neoplasia }\end{array}$} & \multicolumn{2}{|c|}{$\begin{array}{c}\text { Non-significant } \\
\text { pathology }\end{array}$} & \multirow[b]{2}{*}{$P$-value } & \multirow{2}{*}{$\begin{array}{c}\text { Risk of advanced neoplasia } \\
\text { (multivariate analysis) } \\
\text { OR }\end{array}$} & \multirow[b]{2}{*}{$95 \% \mathrm{Cl}$} & \multirow[b]{2}{*}{$P$-value } \\
\hline & $n$ & $\%$ & $n$ & $\%$ & $\mathbf{n}$ & $\%$ & & & & \\
\hline & 3043 & & 1704 & & 1339 & & & & & \\
\hline \multicolumn{11}{|l|}{ Age } \\
\hline$\leqslant 55$ & 565 & 19 & 263 & 15 & 302 & 23 & & 1 & & \\
\hline $56-64$ & 925 & 30 & 513 & 30 & 412 & 31 & & 1.48 & $1.19-1.83$ & $<0.001$ \\
\hline$\geqslant 65$ & 1553 & 51 & 928 & 55 & 625 & 47 & $<0.001$ & 1.89 & $1.55-2.31$ & $<0.001$ \\
\hline \multicolumn{11}{|l|}{ Sex } \\
\hline Male & 1990 & 65 & 1201 & 70 & 780 & 59 & & 1 & & \\
\hline Female & 1053 & 35 & 503 & 30 & 550 & 41 & $<0.001$ & 1.70 & $1.46-1.99$ & $<0.001$ \\
\hline \multicolumn{11}{|c|}{ Deprivation category } \\
\hline 1 (most deprived) & 1060 & 35 & 554 & 33 & 506 & 38 & & 1 & & \\
\hline 2 & 568 & 19 & 324 & 19 & 244 & 18 & & 1.16 & $0.94-1.43$ & 0.16 \\
\hline 3 & 507 & 17 & 278 & 16 & 228 & 17 & & 1.05 & $0.85-1.31$ & 0.653 \\
\hline 4 & 380 & 13 & 232 & 14 & 148 & 11 & & 1.33 & $1.04-1.70$ & 0.021 \\
\hline 5 (least deprived) & 525 & 17 & 313 & 18 & 212 & 16 & $<0.001$ & 1.29 & $1.04-1.60$ & 0.021 \\
\hline \multicolumn{11}{|c|}{ Type of positive stool test } \\
\hline gFOBt & 561 & 18 & 353 & 21 & 208 & 16 & & 1 & & \\
\hline FIT & 2482 & 82 & 1351 & 79 & 1131 & 84 & $<0.001$ & 1.39 & $1.14-1.68$ & 0.001 \\
\hline \multicolumn{11}{|l|}{ Aspirin } \\
\hline No & 2592 & 85 & 1488 & \begin{tabular}{|l|}
87 \\
\end{tabular} & 1104 & 82 & & & & \\
\hline Yes & 451 & 15 & 216 & 13 & 235 & 18 & $<0.001$ & & & \\
\hline \multicolumn{11}{|l|}{ Statin } \\
\hline No & 2422 & 80 & 1409 & 83 & 1013 & 76 & & & & \\
\hline Yes & 621 & 20 & 295 & 17 & 326 & 24 & $<0.001$ & & & \\
\hline \multicolumn{11}{|l|}{ ACE inhibitor } \\
\hline No & 2672 & 88 & 1524 & 89 & 1148 & 86 & & & & \\
\hline Yes & 371 & 12 & 180 & 11 & 191 & 14 & 0.002 & & & \\
\hline \multicolumn{11}{|c|}{$\geqslant 1$ Medications } \\
\hline No & 2271 & 75 & 1330 & 78 & 941 & 70 & & 1 & & \\
\hline Yes & 772 & 25 & 374 & 22 & 398 & 30 & $<0.001$ & 0.59 & $0.50-0.70$ & $<0.001$ \\
\hline
\end{tabular}

Table 3. Combinations of medications and risk of advanced neoplasia in those with colorectal pathology at colonoscopy

\begin{tabular}{|c|c|c|c|c|c|c|c|c|}
\hline & \multicolumn{2}{|c|}{ Aspirin } & \multicolumn{2}{|c|}{ Statin } & \multicolumn{2}{|c|}{ ACE-i } & \multicolumn{2}{|c|}{ Aspirin and Statin } \\
\hline All patients, $n$ & \multicolumn{2}{|c|}{451} & \multicolumn{2}{|c|}{621} & \multicolumn{2}{|c|}{371} & \multicolumn{2}{|c|}{371} \\
\hline OR (95\% Cl) & $0.68(0.56-0.83)$ & $P<0.001$ & $0.65(0.55-0.78)$ & $P<0.001$ & $0.71(0.57-0.89)$ & $P=0.002$ & & \\
\hline \multicolumn{9}{|c|}{ Aspirin, $n(\%)$} \\
\hline $\begin{array}{l}\text { No } \\
\text { Yes }\end{array}$ & & & \multicolumn{2}{|c|}{$\begin{array}{l}250(40) \\
371(60)\end{array}$} & \multicolumn{2}{|c|}{$\begin{array}{l}170(46) \\
201(54)\end{array}$} & & \\
\hline OR $(95 \% \mathrm{Cl})$ & & & $0.69(0.56-0.86)$ & $P=0.001$ & $0.67(0.51-0.90)$ & $P=0.006$ & & \\
\hline \multicolumn{9}{|l|}{ Statin, $n(\%)$} \\
\hline $\begin{array}{l}\text { No } \\
\text { Yes }\end{array}$ & & & & & \multicolumn{2}{|c|}{$\begin{array}{c}93(25) \\
278(75)\end{array}$} & & \\
\hline OR (95\% Cl) & & & & & $0.64(0.50-0.83)$ & $P<0.001$ & & \\
\hline \multicolumn{9}{|l|}{ ACE-i, $n(\%)$} \\
\hline $\begin{array}{l}\text { No } \\
\text { Yes }\end{array}$ & & & & & & & \multicolumn{2}{|c|}{$\begin{array}{l}192(52) \\
179(48)\end{array}$} \\
\hline OR (95\% Cl) & & & & & & & $0.66(0.49-0.90)$ & $P=0.007$ \\
\hline
\end{tabular}


Table 4. Risk of cancer in those with advanced neoplasia at colonoscopy

\begin{tabular}{|c|c|c|c|c|c|c|c|c|c|c|}
\hline & \multicolumn{2}{|c|}{$\begin{array}{c}\text { All } \\
\text { patients }\end{array}$} & \multicolumn{2}{|c|}{ Cancer } & \multicolumn{2}{|c|}{$\begin{array}{l}\text { Advanced } \\
\text { adenoma }\end{array}$} & \multirow[b]{2}{*}{$\boldsymbol{P}$-value } & \multirow{2}{*}{$\begin{array}{c}\text { Risk of cancer } \\
\text { (multivariate } \\
\text { analysis) }\end{array}$} & \multirow[b]{2}{*}{$95 \% \mathrm{Cl}$} & \multirow[b]{2}{*}{$P$-value } \\
\hline & $n$ & $\%$ & $n$ & $\%$ & $n$ & $\%$ & & & & \\
\hline & 1704 & & 392 & & 1312 & & & & & \\
\hline \multicolumn{11}{|l|}{ Age } \\
\hline $\begin{array}{l}\leqslant 55 \\
56-64 \\
\geqslant 65\end{array}$ & $\begin{array}{l}263 \\
513 \\
928\end{array}$ & $\begin{array}{l}15 \\
30 \\
55\end{array}$ & \begin{tabular}{|c|}
46 \\
104 \\
242 \\
\end{tabular} & \begin{tabular}{|l|}
12 \\
27 \\
62 \\
\end{tabular} & $\begin{array}{l}217 \\
409 \\
686\end{array}$ & $\begin{array}{l}17 \\
31 \\
52\end{array}$ & 0.001 & $\begin{array}{c}1 \\
1.22 \\
1.72 \\
\end{array}$ & $\begin{array}{l}0.82-1.80 \\
1.20-2.45\end{array}$ & $\begin{array}{l}0.323 \\
0.003\end{array}$ \\
\hline \multicolumn{11}{|l|}{ Sex } \\
\hline $\begin{array}{l}\text { Male } \\
\text { Female }\end{array}$ & \begin{tabular}{|c|}
1201 \\
503
\end{tabular} & $\begin{array}{l}70 \\
30\end{array}$ & \begin{tabular}{|l|}
260 \\
132
\end{tabular} & $\begin{array}{l}66 \\
34\end{array}$ & $\begin{array}{l}941 \\
371\end{array}$ & $\begin{array}{l}72 \\
28\end{array}$ & 0.04 & $\begin{array}{c}1 \\
0.75\end{array}$ & $0.59-0.96$ & 0.023 \\
\hline \multicolumn{11}{|l|}{$\begin{array}{l}\text { Deprivation } \\
\text { category }\end{array}$} \\
\hline $\begin{array}{l}1 \text { (most deprived) } \\
2 \\
3 \\
4 \\
5 \text { (least deprived) }\end{array}$ & $\begin{array}{l}554 \\
324 \\
278 \\
232 \\
313\end{array}$ & \begin{tabular}{|l|}
33 \\
19 \\
16 \\
14 \\
18
\end{tabular} & \begin{tabular}{|c|}
118 \\
66 \\
72 \\
63 \\
71
\end{tabular} & \begin{tabular}{|l|}
30 \\
17 \\
19 \\
16 \\
18
\end{tabular} & $\begin{array}{l}436 \\
258 \\
206 \\
169 \\
242\end{array}$ & $\begin{array}{l}33 \\
20 \\
16 \\
13 \\
19\end{array}$ & 0.184 & & & \\
\hline \multicolumn{11}{|c|}{ Type of positive stool test } \\
\hline $\begin{array}{l}\text { gFOBt } \\
\text { FIT }\end{array}$ & \begin{tabular}{|c|}
353 \\
1351 \\
\end{tabular} & $\begin{array}{l}21 \\
79 \\
\end{array}$ & $\begin{array}{l}128 \\
264\end{array}$ & $\begin{array}{l}33 \\
67 \\
\end{array}$ & $\begin{array}{c}225 \\
1087\end{array}$ & $\begin{array}{l}17 \\
83\end{array}$ & $<0.001$ & $\begin{array}{c}1 \\
2.41\end{array}$ & $1.87-3.12$ & $<0.001$ \\
\hline \multicolumn{11}{|l|}{ Aspirin } \\
\hline $\begin{array}{l}\text { No } \\
\text { Yes }\end{array}$ & $\begin{array}{c}1488 \\
216\end{array}$ & $\begin{array}{l}87 \\
13\end{array}$ & $\begin{array}{c}349 \\
43\end{array}$ & \begin{tabular}{|l|}
89 \\
11
\end{tabular} & $\begin{array}{c}1139 \\
173\end{array}$ & $\begin{array}{l}87 \\
13\end{array}$ & 0.247 & & & \\
\hline \multicolumn{11}{|l|}{ Statin } \\
\hline $\begin{array}{l}\text { No } \\
\text { Yes }\end{array}$ & \begin{tabular}{|c|}
1409 \\
295
\end{tabular} & \begin{tabular}{|l|}
83 \\
17
\end{tabular} & $\begin{array}{c}336 \\
56\end{array}$ & \begin{tabular}{|l|}
86 \\
14
\end{tabular} & $\begin{array}{c}1073 \\
239\end{array}$ & $\begin{array}{l}82 \\
18\end{array}$ & 0.071 & & & \\
\hline \multicolumn{11}{|l|}{ ACE-i } \\
\hline $\begin{array}{l}\text { No } \\
\text { Yes }\end{array}$ & \begin{tabular}{|c}
1524 \\
180
\end{tabular} & $\begin{array}{l}89 \\
11\end{array}$ & \begin{tabular}{|c}
353 \\
39
\end{tabular} & \begin{tabular}{|l|}
90 \\
10
\end{tabular} & $\begin{array}{c}1171 \\
141\end{array}$ & $\begin{array}{l}89 \\
11\end{array}$ & 0.652 & & & \\
\hline \multicolumn{11}{|l|}{$\geqslant 1$ Medications } \\
\hline $\begin{array}{l}\text { No } \\
\text { Yes }\end{array}$ & \begin{tabular}{|c}
1330 \\
374
\end{tabular} & \begin{tabular}{|l|}
78 \\
22 \\
\end{tabular} & \begin{tabular}{|l}
318 \\
74
\end{tabular} & \begin{tabular}{|l|}
81 \\
19 \\
\end{tabular} & $\begin{array}{c}1012 \\
300\end{array}$ & $\begin{array}{l}77 \\
23 \\
\end{array}$ & 0.094 & & & \\
\hline
\end{tabular}

economically deprived, and that those who fail to progress to colonoscopy following a positive test are more likely to be deprived (Mansouri et al, 2013). Further work exploring medication usage and subsequent development of neoplasia in those who choose not to participate in screening is required.

A limitation of the present study is that data on dosage, duration or compliance with use of these medications were not collected. Therefore, we were not able to draw conclusions on favoured dosing for chemoprevention, nor were we able to separate those who had taken these medications for a period of weeks from those that had been on them for several years. Furthermore, a potential concern of the present cross-sectional study design is that the medication recorded does not reflect ongoing exposure. Nevertheless, given that the recorded medications are used to treat existing co-morbid disease it is likely that such medication would be taken on an ongoing basis. In addition, the majority of patients who were on at least one of these medications were in fact on several of them. Therefore, performing multivariate analysis to assess which was of most importance with this large degree of multicollinearity was not meaningful and the effect of an individual medication could not be reliably estimated. However, this represents a real-life population setting where the majority of patients are likely to be on a combination of medications. Analysis of the risk of neoplasia and the association with medication usage, stratified for location within the colon was also not performed. Previous studies have found the greatest risk reduction with aspirin usage and with lesions of the proximal colon (Rothwell et al, 2010) and hence examining this in our population may have been of interest. However, there is an inherent problem with using data derived from occult blood stool-based colorectal cancer screening programmes for this, as such screening tests are less sensitive for right-sided lesions (Logan et al, 2012). This altered sensitivity creates a skewed study population undergoing colonoscopy where lesions are mainly on the left side of the colon. For example, only $17 \%$ of those with significant neoplasia in our study population had isolated right-sided lesions (data not presented). Such sample bias would negate any meaningful conclusions being drawn from subanalysis based on the location of neoplastic lesions and so such 
an analysis was not undertaken. Also, while consideration was made to adjust for age, sex and socioeconomic deprivation, there are other potential confounding factors such as a significant family history or previous history of colonic neoplasia that have not been included in the present analysis. In particular, there is now robust evidence that patients with hereditary non-polyposis colorectal cancer or familial adenomatous polyposis may derive substantial benefit from aspirin chemoprophylaxis (Burn et al, 2011a,b). However, the overall incidence of these hereditary cancers in our study population is likely to be small $(<10 \%)$.

In conclusion, we report that there is a reduced incidence of advanced colorectal neoplasia in patients who are on aspirin, statins or ACE-i undergoing colonoscopy following a positive stool test within a population-based screening programme. This effect persists when adjustment is made for the possible false-positivity effect of aspirin on gFOBt testing, suggesting that this reduction may be owing to a chemopreventative mechanism. Overall, this supports the theory that population-based usage of these medications in this age group may reduce the incidence of colorectal neoplasia. Further work is required to explore not only this concept but the perceived association with the host systemic inflammatory response, within the context of a national bowel screening programme.

\section{REFERENCES}

Atkin WS, Saunders BP (2002) Surveillance guidelines after removal of colorectal adenomatous polyps. Gut 51(Suppl 5): V6-V9.

Bardou M, Barkun A, Martel M (2010) Effect of statin therapy on colorectal cancer. Gut 59: 1572-1585.

Baron JA, Cole BF, Sandler RS, Haile RW, Ahnen D, Bresalier R, McKeownEyssen G, Summers RW, Rothstein R, Burke CA, Snover DC, Church TR, Allen JI, Beach M, Beck GJ, Bond JH, Byers T, Greenberg ER, Mandel JS, Marcon N, Mott LA, Pearson L, Saibil F, van Stolk RU (2003) A randomized trial of aspirin to prevent colorectal adenomas. $N$ Engl J Med 348: 891-899.

Benamouzig R, Deyra J, Martin A, Girard B, Jullian E, Piednoir B, Couturier D, Coste T, Little J, Chaussade S (2003) Daily soluble aspirin and prevention of colorectal adenoma recurrence: one-year results of the APACC trial. Gastroenterology 125: 328-336.

Brenner H, Tao S, Haug U (2010) Low-dose aspirin use and performance of immunochemical fecal occult blood tests. JAMA 304: 2513-2520.

Burn J, Bishop DT, Chapman PD, Elliott F, Bertario L, Dunlop MG, Eccles D, Ellis A, Evans DG, Fodde R, Maher ER, Möslein G, Vasen HF, Coaker J, Phillips RK, Bülow S, Mathers JC (2011a) A randomized placebo-controlled prevention trial of aspirin and/or resistant starch in young people with familial adenomatous polyposis. Cancer Prev Res (Phila) 4: 655-665.

Burn J, Gerdes AM, Macrae F, Mecklin JP, Moeslein G, Olschwang S, Eccles D, Evans DG, Maher ER, Bertario L, Bisgaard ML, Dunlop MG, Ho JW, Hodgson SV, Lindblom A, Lubinski J, Morrison PJ, Murday V, Ramesar R, Side L, Scott RJ, Thomas HJ, Vasen HF, Barker G, Crawford G, Elliott F, Movahedi M, Pylvanainen K, Wijnen JT, Fodde R, Lynch HT, Mathers JC, Bishop DT (2011b) Long-term effect of aspirin on cancer risk in carriers of hereditary colorectal cancer: an analysis from the CAPP2 randomised controlled trial. Lancet 378: 2081-2087.

Cancer Research UK. Available at http://info.cancerresearchuk.org/ cancerstats/(Accessed January 2013).

Chan AT, Arber N, Burn J, Chia WK, Elwood P, Hull MA, Logan RF, Rothwell PM, Schror K, Baron JA (2012) Aspirin in the chemoprevention of colorectal neoplasia: an overview. Cancer Prev Res (Phila) 5: 164-178.

Clarke P, Jack F, Carey FA, Steele RJ (2006) Medications with anticoagulant properties increase the likelihood of a negative colonoscopy in faecal occult blood test population screening. Colorectal Dis 8: 389-392.

Cole BF, Logan RF, Halabi S, Benamouzig R, Sandler RS, Grainge MJ, Chaussade S, Baron JA (2009) Aspirin for the chemoprevention of colorectal adenomas: meta-analysis of the randomized trials. J Natl Cancer Inst 101: 256-266.

Flossmann E, Rothwell PM (2007) Effect of aspirin on long-term risk of colorectal cancer: consistent evidence from randomised and observational studies. Lancet 369: 1603-1613.
Fraser CG, Digby J, McDonald PJ, Strachan JA, Carey FA, Steele RJ (2012) Experience with a two-tier reflex gFOBT/FIT strategy in a national bowel screening programme. J Med Screen 19: 8-13.

Gauthaman K, Fong CY, Bongso A (2009) Statins, stem cells, and cancer. J Cell Biochem 106: 975-983.

Guittet L, Bouvier V, Mariotte N, Vallee JP, Arsène D, Boutreux S, Tichet J, Launoy G (2007) Comparison of a guaiac based and an immunochemical faecal occult blood test in screening for colorectal cancer in a general average risk population. Gut 56: 210-214.

Hardcastle JD, Chamberlain JO, Robinson MH, Moss SM, Amar SS, Balfour TW, James PD, Mangham CM (1996) Randomised controlled trial of faecal-occult-blood screening for colorectal cancer. Lancet 348: 1472-1477.

Hol L, Wilschut JA, van Ballegooijen M, van Vuuren AJ, van der Valk H, Reijerink JC, van der Togt AC, Kuipers EJ, Habbema JD, van Leerdam ME (2009) Screening for colorectal cancer: random comparison of guaiac and immunochemical faecal occult blood testing at different cut-off levels. $\mathrm{Br} J$ Cancer 100: 1103-1110.

Jacobs RJ, Kodach LL, Hardwick JC (2011) The potential of statins for individualized colorectal cancer chemoprevention. Curr Drug Targets 12: 1903-1908.

Kedika R, Patel M, Pena Sahdala HN, Mahgoub A, Cipher D, Siddiqui AA (2011) Long-term use of angiotensin converting enzyme inhibitors is associated with decreased incidence of advanced adenomatous colon polyps. J Clin Gastroenterol 45: e12-e16.

Kronborg O, Fenger C, Olsen J, Jorgensen OD, Sondergaard O (1996) Randomised study of screening for colorectal cancer with faecal-occultblood test. Lancet 348: 1467-1471.

Lee CS, McNamara D, O'Morain CA (2012) Aspirin as a chemoprevention agent for Colorectal cancer. Curr Drug Metab 13: 1313-1322.

Lee TJ, Hull MA, Rajasekhar PT, Clifford GM, Ritchie M, James P, McNally RJ, Rutter MD, Rees CJ (2012) Aspirin users attending for NHS bowel cancer screening have less colorectal neoplasia: chemoprevention or false-positive faecal occult blood testing? Digestion 85: 278-281.

Lever AF, Hole DJ, Gillis CR, McCallum IR, McInnes GT, MacKinnon PL, Meredith PA, Murray LS, Reid JL, Robertson JW (1998) Do inhibitors of angiotensin-I-converting enzyme protect against risk of cancer? Lancet 352: 179-184.

Levi Z, Rozen P, Hazazi R, Vilkin A, Waked A, Maoz E, Birkenfeld S, Lieberman N, Klang S, Niv Y (2009) Sensitivity, but not specificity, of a quantitative immunochemical fecal occult blood test for neoplasia is slightly increased by the use of low-dose aspirin, NSAIDs, and anticoagulants. Am J Gastroenterol 104: 933-938.

Logan RF, Patnick J, Nickerson C, Coleman L, Rutter MD, von Wagner C (2012) Outcomes of the Bowel Cancer Screening Programme (BCSP) in England after the first 1 million tests. Gut 61: 1439-1446.

Mandel JS, Bond JH, Church TR, Snover DC, Bradley GM, Schuman LM, Ederer F (1993) Reducing mortality from colorectal cancer by screening for fecal occult blood. Minnesota Colon Cancer Control Study. N Engl J Med 328: 1365-1371.

Mansouri D, McMillan DC, Grant Y, Crighton EM, Horgan PG (2013) The impact of age, sex and socioeconomic deprivation on outcomes in a colorectal cancer screening programme. PLoS One. Article accepted but not yet published.

Parra-Blanco A, Gimeno-García AZ, Quintero E, Nicolás D, Moreno SG, Jiménez A, Hernández-Guerra M, Carrillo-Palau M, Eishi Y, LópezBastida J (2010) Diagnostic accuracy of immunochemical versus guaiac faecal occult blood tests for colorectal cancer screening. J Gastroenterol 45: 703-712.

Poynter JN, Gruber SB, Higgins PD, Almog R, Bonner JD, Rennert HS, Low M, Greenson JK, Rennert G (2005) Statins and the risk of colorectal cancer. N Engl J Med 352: 2184-2192.

Proctor MJ, Talwar D, Balmar SM, O’Reilly DS, Foulis AK, Horgan PG, Morrison DS, McMillan DC (2010) The relationship between the presence and site of cancer, an inflammation-based prognostic score and biochemical parameters. Initial results of the Glasgow Inflammation Outcome Study. Br J Cancer 103: 870-876.

Rocken C, Neumann K, Carl-McGrath S, Lage H, Ebert MP, Dierkes J, Jacobi CA, Kalmuk S, Neuhaus P, Neumann U (2007) The gene polymorphism of the angiotensin I-converting enzyme correlates with tumor size and patient survival in colorectal cancer patients. Neoplasia 9: 716-722.

Rodgers A, Patel A, Berwanger O, Bots M, Grimm R, Grobbee DE, Jackson R, Neal B, Neaton J, Poulter N, rafter N, Raju PK, Reddy S, Thom S, Vander 
Hoorn S, Webster R (2011) An international randomised placebocontrolled trial of a four-component combination pill ("polypill") in people with raised cardiovascular risk. PLoS One 6: e19857.

Rothwell PM, Fowkes FG, Belch JF, Ogawa H, Warlow CP, Meade TW (2011) Effect of daily aspirin on long-term risk of death due to cancer: analysis of individual patient data from randomised trials. Lancet 377: 31-41.

Rothwell PM, Wilson M, Elwin CE, Norrving B, Algra A, Warlow CP, Meade TW (2010) Long-term effect of aspirin on colorectal cancer incidence and mortality: 20-year follow-up of five randomised trials. Lancet $\mathbf{3 7 6}$ : 1741-1750.

Sandler RS, Halabi S, Baron JA, Budinger S, Paskett E, Keresztes R, Petrelli N, Pipas JM, Karp DD, Loprinzi CL, Steinbach G, Schilsky R (2003) A randomized trial of aspirin to prevent colorectal adenomas in patients with previous colorectal cancer. N Engl J Med 348: 883-890.

Sawhney MS, McDougall H, Nelson DB, Bond JH (2010) Fecal occult blood test in patients on low-dose aspirin, warfarin, clopidogrel, or non-steroidal anti-inflammatory drugs. Dig Dis Sci 55: 1637-1642.

Simon MS, Rosenberg CA, Rodabough RJ, Greenland P, Ockene I, Roy HK, Lane DS, Cauley JA, Khandekar J (2012) Prospective analysis of association between use of statins or other lipid-lowering agents and colorectal cancer risk. Ann Epidemiol 22: 17-27.
Steele RJ, McClements P, Watling C, Libby G, Weller D, Brewster DH, Black R, Carey FA, Fraser CG (2012) Interval cancers in a FOBT-based colorectal cancer population screening programme: implications for stage, gender and tumour site. Gut 61: 576-581.

Steele RJ, McClements PL, Libby G, Black R, Morton C, Birrell J, Mowat NA, Wilson JA, Kenicer M, Carey FA, Fraser CG (2009) Results from the first three rounds of the Scottish demonstration pilot of FOBT screening for colorectal cancer. Gut 58: 530-535.

Thun MJ, Namboodiri MM, Heath Jr. CW (1991) Aspirin use and reduced risk of fatal colon cancer. N Engl J Med 325: 1593-1596.

Wald NJ, Law MR (2003) A strategy to reduce cardiovascular disease by more than $80 \%$. BMJ 326: 1419.

Zhou P, Cheng SW, Yang R, Wang B, Liu J (2012) Combination chemoprevention: future direction of colorectal cancer prevention. Eur J Cancer Prev 21: 231-240.

This work is published under the standard license to publish agreement. After 12 months the work will become freely available and the license terms will switch to a Creative Commons AttributionNonCommercial-Share Alike 3.0 Unported License. 